\title{
Structure of Pd-Zr and Pt-Zr modified aluminide coatings deposited by a CVD method on nickel superalloys
}

\author{
M. Pytel ${ }^{1}$, T. Tokarski ${ }^{2}$, Góral $^{1 *}$, R. Filip ${ }^{1}$ \\ ${ }^{1}$ Department of Materials Science, Research and Development Laboratory for Aerospace Materials, \\ Rzeszow University of Technology, Powstancow Warszawy 12, 35-959 Rzeszow, Poland \\ ${ }^{2}$ AGH University of Science and Technology, Academic Centre for Materials and Nanotechnology, \\ A. Mickiewicza Av. sl 30, 30-059 Krakow, Poland
}

Received 7 March 2019, received in revised form 10 June 2019, accepted 11 June 2019

\begin{abstract}
In this paper, the structure of newly developed modified aluminide coatings is characterized. The platinum and palladium coatings were obtained by an electroplating process. The $\mathrm{Pt}$ and $\mathrm{Pd}$ electroplated samples were aluminized and also modified by zirconium doping during the CVD (Chemical Vapour Deposition) low-activity process. Aluminide coatings were deposited using industrial CVD system. In the paper, the process parameters are described as well as the results of the microstructural analysis. The chemical and microstructure analysis was conducted using electron microscopes equipped with an energy dispersive spectrometer attachment. The phase composition analysis was performed using an X-ray diffractometer and showed that the aluminide coatings (Pt-Zr and Pd-Zr modified) obtained by CVD low-activity aluminizing comprised $\beta$-NiAl phase grains enriched in platinum (max. approx. 16 at.\% of $\mathrm{Pt}$ ) or palladium (max. approx. 21 at.\% of $\mathrm{Pd}$ ). The coatings consisted of two or three zones. The first outer zone was a single phase $-(\mathrm{Ni}, \mathrm{Pt} / \mathrm{Pd}) \mathrm{Al}$ type. The aluminium-content of the outer zone of the platinum modified aluminide coating was approx. 45 at.\%, while aluminiumcontent in the outer zone of the palladium modified aluminide coatings was approx. 52 at.\%. The results showed that the total thickness of aluminide coatings was an average of about $50 \mu \mathrm{m}$ while the average thickness of the outer $\beta$-NiAl zone was about $35 \mu \mathrm{m}$. These types of aluminide coating are applied to the thermal barrier coatings with a ceramic outer layer produced by EB-PVD (electron beam physical vapour deposition) or hybrid LPPS PS-PVD (Low-Pressure Plasma PS-PVD) methods.
\end{abstract}

K e y wo r d s: aluminide coatings, low-activity aluminizing/zirconizing, CVD method, $\mathrm{Pd} / \mathrm{Zr}-\mathrm{Pt} / \mathrm{Zr}$ modified aluminide coatings

\section{Introduction}

Construction elements of the gas turbine in aircraft engines, particularly blades, and also vanes, rotors, stators, and others work under conditions of extreme heat and mechanical load and are exposed to multiple states of stresses and strains. They are also exposed to the destructive and corrosive effects of the hot oxidizing environment of the combustion gases. Among factors affecting the life of elements of the hot section in aircraft engines are high-temperature oxidation, hot corrosion, high-temperature corrosion, hot erosion, fatigue, thermal shocks, etc. Over the last 20 years turbine entry temperature has increased from $920-1030{ }^{\circ} \mathrm{C}$ to $1400-1500^{\circ} \mathrm{C}$. An increase in temperature of the turbine directly influences unit power and the power transmission system as well as causing an increase in combustion efficiency. Another target is to increase the working life of modern aircraft engines as well as their durability and reliability. Achievement of these aims requires the application of layers and protective coatings on the substrate material, i.e., nickel superalloy. It is said that, currently, layers and protective coatings cover $70-80 \%$ of the elements of aircraft engine parts $[1-6]$.

Due to the extreme working conditions in aircraft

*Corresponding author: e-mail address: mgoral@prz.edu.pl 
engines, there are various protective materials used in aerospace engineering, among these are materials of metallic, ceramic, and composite matrix. Used to increase the durability of particular elements and entire units, protective coatings are made by various methods depending on their structure, qualities, and application. There are diffusion coatings as well as adhesive coatings formed by physical deposition methods.

Nowadays, the most commonly used are three methods of diffusion aluminide coatings manufacturing: Pack-Cementation method, Vapour Phase Aluminizing (Above The Pack and Out Of Pack processes) and Chemical Vapour Deposition method (lowand high-activity methods). The protective and heatresistant coatings can also be formed by the "Slurry" method in the dip-coating process and chromium and silicon modified. The most advanced types of protective coatings are Thermal Barrier Coatings (TBC's). These are made up of a system of composite-type coatings [4-9].

Thermal barrier coatings are very often built of an aluminide coating (very often platinum or palladium modified), which acts as a bond coat and an outer ceramic layer based on yttria-stabilized zirconia (YSZ) $\mathrm{ZrO}_{2} \cdot \mathrm{Y}_{2} \mathrm{O}_{3}$ (approx. 7-8 wt.\% of $\mathrm{Y}_{2} \mathrm{O}_{3}$ ). YSZ layers are commercially produced by EB-PVD or LowPressure Plasma Spraying (LPPS PS-PVD) as well as High-Velocity Oxygen Fuel (HVOF). One of the oldest methods is Atmospheric Plasma Spraying (APS) [10-15].

It must be observed that each of the forementioned methods has at least a few different types that influence the chemical, phase, and structural composition of the coating. Aluminide coatings on the base of nickel aluminides from the $\mathrm{Ni}-\mathrm{Al}$ phase diagram are an alternative to NiCrAlY and NiCoCrAlY-type coatings. These are formed on the matrix consisting of grains of the intermetallic $\beta-\mathrm{NiAl}$ phase (for $\mathrm{MCrAlY}$ layers the matrix is the $\gamma$-NiCrAlY phase, whereas the $\beta$-NiAl phase is observed in precipitates), which offer the best resistance to high-temperature oxidation and high-temperature corrosion among known aluminide phases. The thermodynamically stable $\alpha$ $\mathrm{Al}_{2} \mathrm{O}_{3}$ forms on the $\beta$-NiAl surface at the temperature above $1000-1100^{\circ} \mathrm{C}$. During further oxidation, the alumina scale grows and forms zone of Thermally Grown Oxide (TGO) [16-19].

Many studies claim that aluminide coatings formed in the low-activity CVD process have high heat resistance and thermal stability $[20-22]$. This is due to, among other factors, the layer structure, its chemical and phase composition - thanks to the stoichiometric $\beta$-NiAl phase grains present in the outer layer, formed in a low-activity process. Aluminide coatings formed in this type of CVD process are pure - some authors suggest that the gaseous hydrogen chloride and hydrogen (reducing atmosphere) aid desulphurization of the substrate material and coatings. This fact influences the quality and properties of aluminide coatings. Their heat resistance is much improved. Aluminide coatings modified with precious metals such as platinum and palladium are currently used for commercial purposes [23-25]. Some studies also take the possibility of using other precious metals, such as iridium and also rareearth elements [26]. Aluminide coatings deposited in a high-activity are formed by the inward diffusion of aluminium, which content is from 50 at. $\%$ up to approx. 60 at.\%. This is a result of placing additional amounts of chromium-aluminium granules in the main retort. Adding these granules may lead to the introduction of unwanted impurities. Subsequent diffusion annealing and stress relief annealing of these coatings are necessary. The properties and quality of the aluminide coating depend mostly on its thickness, structure, aluminium content, purity, and quantity of other elements (such as chromium, titanium, and cobalt).

Usually, aluminide coatings, containing a matrix of $\beta$-NiAl intermetallic phase and having high aluminium content above 50 at. $\%$, have better resistance to heat corrosion. Conversely, $\beta$-NiAl coatings which have on the average $42-50$ at. $\%$ of the aluminium content are better for high-temperature oxidation. The lifetime of aluminide coatings may be greatly reduced by rapid aluminium loss. Authors Henderkott and also B. Bouchaud et al. claim that under some favourable conditions: cooling rate, aluminium content - when the $\beta$-NiAl matrix is depleted in aluminium and containing less than 38 at.\% of $\mathrm{Al}$, a martensitic transformation occurs from the structure of B2 to the tetragonal ordered $\mathrm{L} 1_{0}$ structure or into the ordered $14 \mathrm{M}$ martensitic structure. This transformation causes internal stresses coupled with a volume change. This transformation is responsible for rumpling and weakens the bonding of the ceramic layer to the aluminide coating [27-30]. Although platinum and palladium content in the $\beta$-NiAl layer helps to maintain high aluminium concentration in the outer zone of the layer, it does not prevent the martensitic transformation. Additionally, in the case of aluminium content dropping below 35 at.\%, a significant decrease in temperature resistance of the layer has been observed. Further, oxidation causes phase transition from the $\beta$-NiAl to the $\gamma^{\prime}-\mathrm{Ni}_{3} \mathrm{Al}$ - grains of this phase are poorly resistant to high-temperature oxidation. To increase the thermal stability of coatings, studies are being carried out into modification of chemical composition and structure with the use of reactive elements such as Hf and Zr as well as rare earth metals such as Y, Er, Ce. The authors M. P. Bacos, J. M. Dorvaux et al., also K. A. Marino, Berit Hinnemann et al. have assumed that the addition of hafnium and zirconium may improve adherence of the alumina scale to the $\beta$ - NiAl coating $[31$, $32]$. These authors claim that the adhesion energy of $\alpha-\mathrm{Al}_{2} \mathrm{O}_{3}(0001)$ to the $\beta$ - $\mathrm{NiAl}(110)$ interface increases 
Ta ble 1. Nominal chemical composition of superalloy Mar M 200+Hf (wt.\%)

\begin{tabular}{ccccccccccc}
\hline $\mathrm{Ni}$ & $\mathrm{C}$ & $\mathrm{Cr}$ & $\mathrm{Co}$ & $\mathrm{W}$ & $\mathrm{Nb}$ & $\mathrm{Ti}$ & $\mathrm{Al}$ & $\mathrm{B}$ & $\mathrm{Hf}$ & $0.8-1.9$ \\
\hline Balance & 0.14 & 9.0 & 10 & 12 & 1.0 & 2.0 & 5.0 & 0.015 & 0 \\
\hline
\end{tabular}

Table 2. Nominal chemical composition of superalloy René 80 (wt.\%)

\begin{tabular}{ccccccccccc}
\hline $\mathrm{Ni}$ & $\mathrm{C}$ & $\mathrm{Cr}$ & $\mathrm{Co}$ & $\mathrm{W}$ & $\mathrm{Mo}$ & $\mathrm{Ti}$ & $\mathrm{Al}$ & $\mathrm{B}$ & $\mathrm{Zr}$ & 0.03 \\
\hline Balance & 0.16 & 14.0 & 9.5 & 4.0 & 4.0 & 5.0 & 3.0 & 0.015 & 0.0 \\
\hline
\end{tabular}

from $0.66 \mathrm{~J} \mathrm{~m}^{-2}$ for the clean interface to $2.06 \mathrm{~J} \mathrm{~m}^{-2}$ for the Hf-doped interface. So they suggest that the effect of $\mathrm{Hf}$ on the $\alpha-\mathrm{Al}_{2} \mathrm{O}_{3}(0001) / \beta$-NiAl (110) interface is astonishingly large even with only $0.1 \mathrm{ML}$ (monolayer) of Hf present.

The introduction of zirconium, hafnium, and yttrium benefits the durability of coatings formed on the grains of the $\beta$-NiAl phase. K. A. Marino et al. concluded that hafnium (as well as a zirconium and yttrium) and oxygen form very strong Hf-O bonds, because of Hf's open d shell, which allows for both polar-covalent and donor-acceptor bonding to flourish. They also stated that Hf forms four mixed polarcovalent/donor-acceptor bonds to oxygen ions at the alumina surface, the origin of its immensely strong adhesion. At the same time, the addition of $\mathrm{Hf}$ and $\mathrm{Y}$ (or any early transition metal, rare earth, and even some alkaline earth) limits the slip along grain boundaries of aluminum oxide due to their strong cross-boundary bonds to oxygen [32]. $\mathrm{HfO}_{2}$ and $\mathrm{ZrO}_{2}$ (so-called pegs) are formed on the surface of the aluminide coating, which improves adherence of the $\alpha-\mathrm{Al}_{2} \mathrm{O}_{3}$ layer to grains of the $\beta$-NiAl phase. Hafnium, zirconium, and yttrium easily segregate to the grain boundaries of polycrystalline $\mathrm{Al}_{2} \mathrm{O}_{3}$ oxide followed by the diffusion of oxygen, thereby slowing the growth of alumina (TGO). Zirconium decreases cracking and brittleness of the polycrystalline $\mathrm{Al}_{2} \mathrm{O}_{3}$ layer - it improves its yield point and decreases tensile stress, which leads to spalling off of alumina scale - this phenomenon is responsible very often for delamination and degradation of TBC. Presence of zirconium and hafnium reduces the formation of Kirkendall pores in the boundary area between the aluminide coating and the alumina scale. Zirconium improves the yield point of the $\beta$ $\mathrm{NiAl}$ phase and limits its susceptibility to martensitic transformation as well as limiting grain boundary sliding. The $\beta$-NiAl(Zr) layer remains undeformed. Residual compressive stresses within the $\mathrm{Al}_{2} \mathrm{O}_{3}$ (TGO) are higher by approx. $1 \mathrm{GPa}$ in comparison with the $\mathrm{Al}_{2} \mathrm{O}_{3}$ layer formed on the aluminide bond coat which has not been zirconium modified. Platinum and palladium content stabilizes the layer and limits the outward diffusion of refractory elements (chromium, niobium, molybdenum, tungsten, tantalum). The presence of $\mathrm{Pt}$ and $\mathrm{Pd}$ limits the formation of brittle and unstable spinels such as (Ni,Cr, $\mathrm{Co}, \mathrm{Ti}) \mathrm{Al}_{2} \mathrm{O}_{4}$ and $\mathrm{NiO}$ oxide. It is also assumed that $\mathrm{Pt}$ limits the harmful effects of sulfur in the coating and superalloy $[32,33]$.

\section{Experimental procedure}

For examination purposes, we used casting rods made of polycrystalline René 80 nickel-base superalloy and directionally solidified with columnar grains (CGDS) Mar M 200+Hf nickel-base superalloy. Samples made of René 80 superalloy were partially heat treated by the following instructions: slow heating up to $1100^{\circ} \mathrm{C}$ at the speed of $10^{\circ} \mathrm{C} \mathrm{min}{ }^{-1}$, next from $1100{ }^{\circ} \mathrm{C}$ up to approx. $1209^{\circ} \mathrm{C}$ at the rate of $5^{\circ} \mathrm{C} \mathrm{min}{ }^{-1}$ to avoid remelting the $\gamma-\gamma^{\prime}$ eutectic (so-called subsolidus heat treatment).

Then cast rods of $14 \mathrm{~mm}$ in diameter and $150 \mathrm{~mm}$ in length were annealed (homogenizing-solution) at a temperature of $1209^{\circ} \mathrm{C}$ for $2 \mathrm{~h}$, next cooled to a temperature of $1094^{\circ} \mathrm{C}$ within approx. $15 \mathrm{~min}$. At a temperature of $1094{ }^{\circ} \mathrm{C}$ the samples were primarily aged for $4 \mathrm{~h}$ and then free cooled in argon until they reached room temperature. Heat treatment was carried out in a high vacuum and argon protective atmosphere at pressure $5 \times 10^{-3} \mathrm{~Pa}$ using a Monotherm Vacuum Furnace by ALD Vacuum Technologies. Samples used in tests were circular - $14 \mathrm{~mm}$ in diameter and $4 \mathrm{~mm}$ thick.

Tables 1, 2 show the nominal chemical composition of the superalloys used in the procedure. The surface of René 80 superalloy samples was electroplated with approx. $7 \mu \mathrm{m}$ of platinum, while the surface of Mar M $200+$ Hf samples was electroplated with approx. $9 \mu \mathrm{m}$ of palladium coating. Electroplating (platinum and palladium) processes were carried out by the method put forward by Yavorska et al. [27]. Then the samples were zirconized-aluminized in the low-activity process by the chemical vapour deposition method (CVD).

Zirconizing-aluminizing processes were carried out in a semi-industrial BPX-Pro325s device by IonBond in the Research and Development Laboratory for 
Table 3. Low-activity aluminizing/zirconizing CVD process parameters

\begin{tabular}{|c|c|c|c|c|c|c|c|c|}
\hline \multirow{4}{*}{ No. } & \multicolumn{4}{|c|}{ Aluminizing } & \multicolumn{4}{|c|}{ Zirconizing } \\
\hline & \multicolumn{8}{|c|}{$\begin{array}{l}\text { Pressure }(\mathrm{Pa}) \\
1.5 \times 10^{-4}\end{array}$} \\
\hline & \multicolumn{2}{|l|}{$\begin{array}{c}\text { Flow rate } \\
\left(\mathrm{dm}^{3} \min ^{-1}\right)\end{array}$} & \multirow[t]{2}{*}{$\begin{array}{c}\text { Time } \\
(\mathrm{h})\end{array}$} & \multirow[t]{2}{*}{$\begin{array}{l}\text { Temperature } \\
\text { (in retort) }\left({ }^{\circ} \mathrm{C}\right)\end{array}$} & \multicolumn{2}{|c|}{$\begin{array}{l}\text { Flow rate } \\
\left(\mathrm{dm}^{3} \min ^{-1}\right)\end{array}$} & \multirow[t]{2}{*}{ Time } & \multirow[t]{2}{*}{$\begin{array}{c}\text { Temperature } \\
\left(\mathrm{ZrCl}_{4} \text { formation }\right)\left({ }^{\circ} \mathrm{C}\right)\end{array}$} \\
\hline & $\mathrm{HCl}+3 \mathrm{dm}^{3} \min ^{-1} \mathrm{H}_{2}$ & $\mathrm{H}_{2}$ & & & $\mathrm{HCl}$ & Ar & & \\
\hline 1 & 0.4 & 7.5 & 8 & 1050 & 0.4 & 2.5 & 2 & 450 \\
\hline
\end{tabular}

Aerospace Materials at the Rzeszów University of Technology. Forming of the $\mathrm{AlCl}_{3}$ precursor was carried out in an outer generator with aluminium pellets (purity $>99.99$ wt.\% $\mathrm{Al}$ ) by running $\mathrm{HCl}$ gas hydrogen chloride, heated up to a temperature of approx. $300^{\circ} \mathrm{C}$ and hydrogen was used as the carrier gas. The $\mathrm{ZlCl}_{4}$ precursor was formed in a separate outer generator, where zirconium pellets (99.99\% purity) were placed, and next $\mathrm{HCl}$ gas hydrogen chloride heated up to a temperature of approx. $450^{\circ} \mathrm{C}$ was run, argon was used as the carrier gas. Reactions of gas $\mathrm{AlCl}_{3}$ and $\mathrm{ZrCl}_{4}$ precursors were carried out by the following reactions, Eqs. (1)-(4):

$$
\begin{aligned}
& \mathrm{Al}_{(\mathrm{s})}+3 \mathrm{HCl}_{(\mathrm{g})} \leftrightarrow \mathrm{AlCl}_{3(\mathrm{~g})}+3 / 2 \mathrm{H}_{2(\mathrm{~g})} \\
& \text { aluminium chloride formation, } \\
& \mathrm{Al}_{(\mathrm{s})}+2 \mathrm{HCl}_{(\mathrm{g})} \leftrightarrow \mathrm{AlCl}_{2(\mathrm{~g})}+\mathrm{H}_{2(\mathrm{~g})}, \\
& \mathrm{Al}_{(\mathrm{s})}+\mathrm{HCl}_{(\mathrm{g})} \leftrightarrow \mathrm{AlCl}_{(\mathrm{g})}+1 / 2 \mathrm{H}_{2(\mathrm{~g})}, \\
& 4 \mathrm{HCl}+\mathrm{Ar}+\mathrm{Zr} \rightarrow \mathrm{ZrCl}_{4(\mathrm{~g})}+2 \mathrm{H}_{2}+\mathrm{Ar} \\
& \quad \text { zirconium chloride formation, }
\end{aligned}
$$

where $\mathrm{g}$ is gaseous state and $\mathrm{s}$ is solid state.

Then both precursors were transported by carrier gases to the main retort of the reactor and heated up to a temperature of approx. $1050{ }^{\circ} \mathrm{C}$, where thermally activated compounds were deposited on a substrate material.

Table 3 presents the conditions of the applied processes. After the zirconizing-aluminizing process, chemical composition analysis was carried out by the SEM-EDS method, and microstructural examinations of the aluminide coatings formed were carried out with the use of S3400N and FE-SEM Su-70 scanning electron microscopes by Hitachi. EDS X-ray maps were also used.

Phase composition analysis was carried out with the use of ARL X'TRA X-ray diffractometer (at $40 \mathrm{kV}$ voltage and heater current of $40 \mathrm{~mA}$, using the $\mathrm{CuK} \alpha_{1}$ radiation $(\lambda=0.154 \mathrm{~nm})$. Specimens were taken in compliance with standard metallographic techniques.

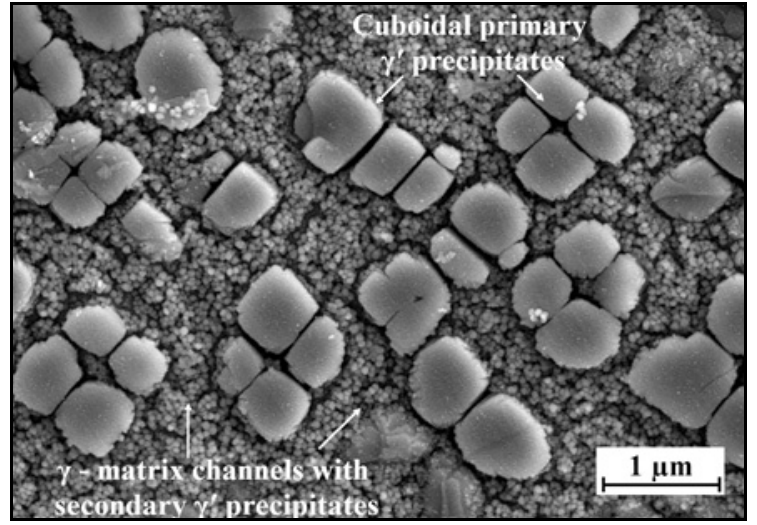

Fig. 1. The microstructure of René 80 superalloy after solution annealing, and the first stage of ageing - visible primary and secondary $\gamma^{\prime}$-phase precipitates.

Samples used for the analysis of superalloy microstructure in the initial state were electrolytically etched with the use of reagents: no $1 .:$ aq. $10 \% \mathrm{H}_{3} \mathrm{PO}_{4}$, no 2.: $2 \mathrm{~g}$ of $\mathrm{CrO}_{3}+100 \mathrm{ml}$ of $\mathrm{H}_{2} \mathrm{O}$. In the electrolytic etching process, a DC of $3 \mathrm{~V}$ was used, current density was approx. $0.2-0.3 \mathrm{~A} \mathrm{~cm}^{-2}$. Cross-sections of obtained aluminide coatings (also for SEM-EDS microanalysis) were polished but not etched.

\section{Results and discussion}

\subsection{Microstructural examinations of substrate materials}

Figure 1 shows the microstructure of the René 80 superalloy after partial heat treatment, which consisted of homogenizing/solution coupled with 1st stage ageing. Cubic precipitates of the $\gamma^{\prime}-\mathrm{Ni}_{3} \mathrm{Al}$ strengthening phase and secondary spheroidal precipitates of the $\gamma^{\prime}$-phase can be observed in the matrix channels. Figures 2a,b show microstructure of the Mar M $200+$ Hf superalloy in the cast state. Numerous $\gamma-\gamma^{\prime}$ eutectics, as well as primary cubic $\gamma^{\prime}$ and secondary spheroidal $\gamma^{\prime}$ precipitates in the matrix channels, have 

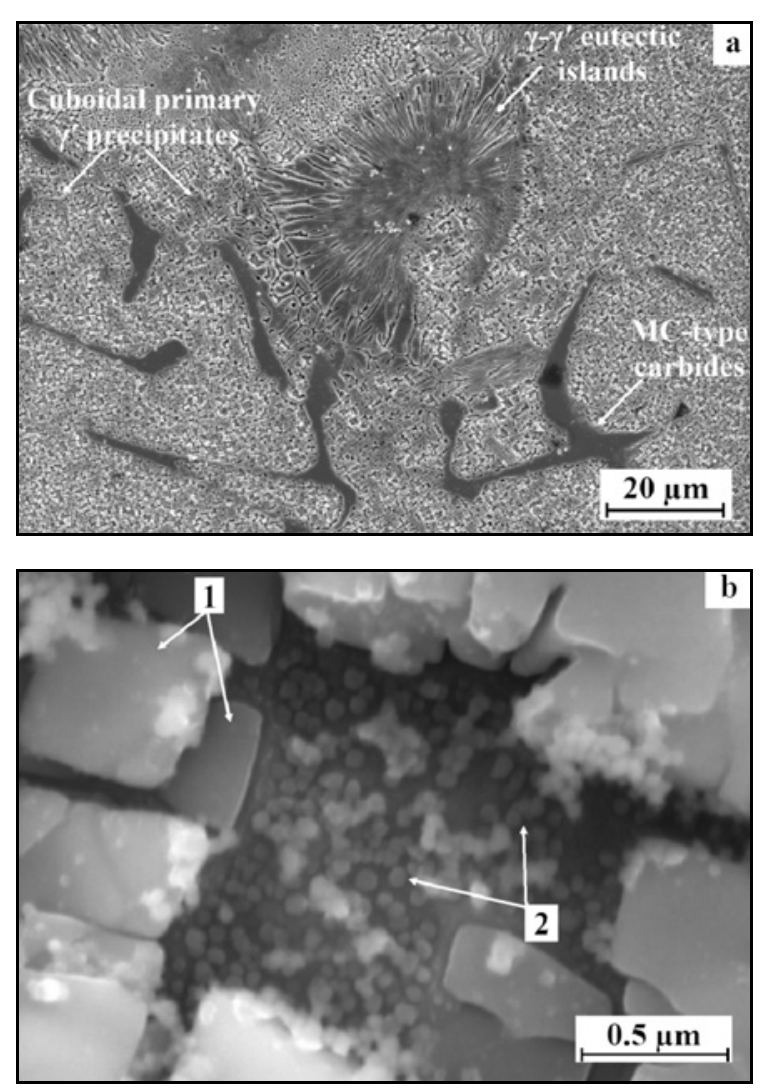

Fig. 2. The microstructure of Mar M 200+Hf superalloy in the as-cast state (A), higher magnification visible matrix channels and ultrafine secondary $\gamma^{\prime}$-phase precipitates, $1-$ primary cuboidal $\gamma$ precipitates, 2 - secondary spheroidal $\gamma$ precipitates in $\gamma$-matrix channels.

been observed, together with primary MC-type carbides (where $\mathrm{M}=\mathrm{Ti}, \mathrm{W}, \mathrm{Ta}$ ) which form a so-called "Chinese script."

\subsection{Characteristics of the microstructure of palladium and platinum layers}

Figure 3a shows the morphology of the platinum coating surface after galvanization, deposited on the René 80 superalloy surface. Figure 3 b contains results of the platinum coating XRD analysis. Results of the SEM-EDS chemical composition of the platinum layer tested in the area marked as shown in Fig. 3a are presented in Fig. 3c and Table 4. Results of the chemical composition and phase analyses have shown that the formed layer was single phase, dense and nonporous. Analysis of chemical composition by EDS showed that the platinum layer was free from impurities. However, it was characterized by slight surface roughness.

Results of the EDS chemical composition analysis, as well as phase and microstructural examinations of palladium coating electroplated on the surface of the Mar M 200+Hf superalloy, are shown in Figs. 4a-d. Figure 4a presents the palladium layer cross-section,
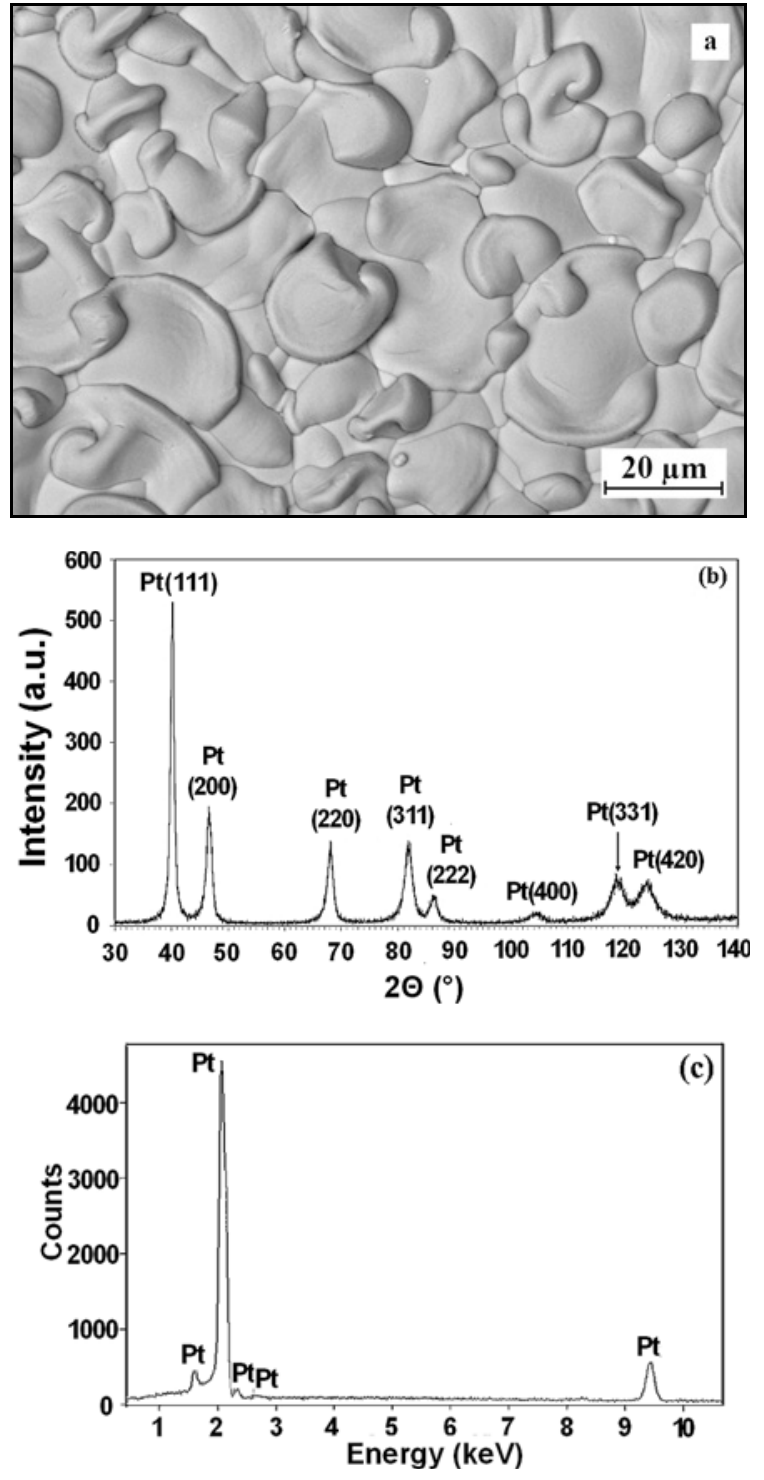

Fig. 3. Microstructure and surface morphology of platinum layer after the galvanizing process, deposited on René 80 superalloy surface (a), XRD diffractogram of Pt layer (b), EDS X-ray spectrum from Pt layer surface.

where three micro areas of the EDS chemical composition analysis were marked. Figure $4 \mathrm{~b}$ shows the EDS $\mathrm{X}$-ray spectrum made in the area of the SEM-EDS chemical composition analysis of the sample surface. Table 5 contains the results of the EDS chemical composition analysis. Results of XRD phase analysis into the palladium layer on the Mar M 200+Hf superalloy (Fig. 4e) show, in addition, the presence of a $\gamma^{\prime}$-phase originating in the substrate material.

\subsection{The microstructure of Pt-Zr modified aluminide coating}

Examination of the aluminide coating microstructure formed on the René 80 superalloy substrate with 

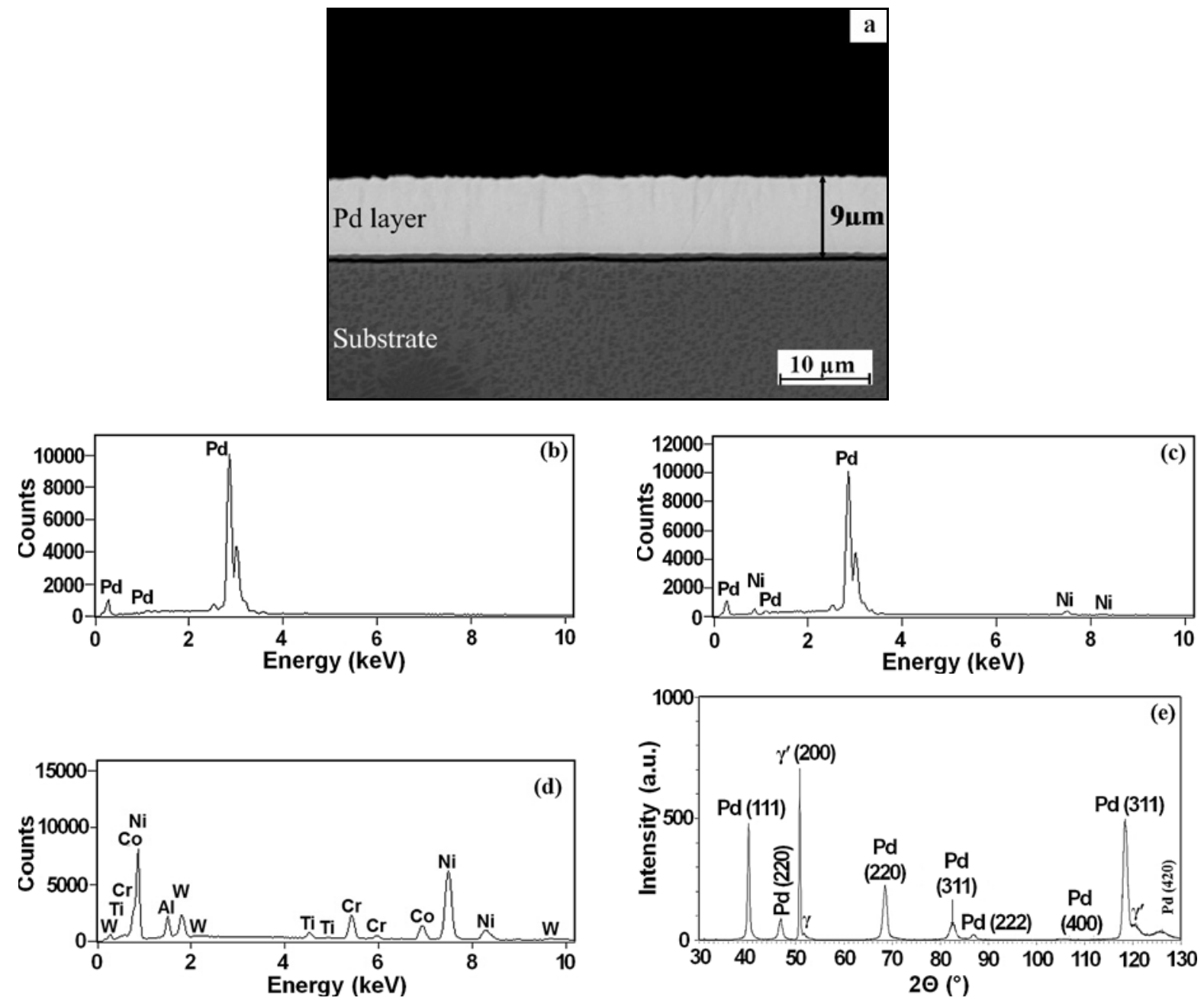

Fig. 4. Cross-section of Pd layer deposited on Mar M 200+Hf superalloy substrate (a), EDS X-ray spectra of micro areas chosen for microanalysis (b)-(d), and results of XRD phase analysis (e).

Table 4. The results of EDS microanalysis of the platinum layer

\begin{tabular}{cccc}
\hline Element line & Net counts & (wt.\%) & (at.\%) \\
\hline Pt L & 14929 & 100.00 & 100.00 \\
Total & - & 100.00 & 100.00 \\
\hline
\end{tabular}

Ta ble 5. Chemical composition (SEM-EDS) in chosen micro areas (Fig. 4)

\begin{tabular}{ccccccccc}
\hline \multirow{2}{*}{ Micro area } & \multicolumn{7}{c}{ Element content (wt.\%) } \\
\cline { 2 - 8 } & Al-K & Ti-K & Cr-K & Co-K & Ni-K & Pd-L & W-L \\
\hline 1 & - & - & - & - & - & 100.00 & - \\
2 & - & - & - & - & 5.70 & 94.30 & 15.44 \\
3 & 4.53 & 1.83 & 9.29 & 10.40 & 58.50 & - & C \\
\hline
\end{tabular}

the platinum galvanic layer (approx. $7 \mu \mathrm{m}$ ) after the low-activity aluminizing-zirconizing process (Table 3) has shown the presence of two different layers, i.e., an outer additive layer, an interdiffusion zone (IDZ) and islands of secondary reaction zone (SRZ). The structure of aluminide coating obtained in low-activity aluminizing-zirconizing CVD process was typical for diffusion coatings. The average thickness of the outer 


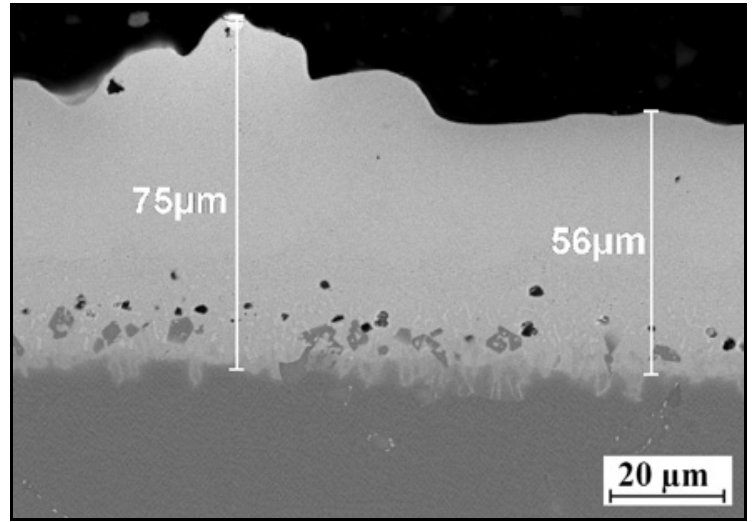

Fig. 5. Microstructure and measured thickness of $\mathrm{Pt}-\mathrm{Zr}$ modified aluminide coating deposited on René 80 surface.

layer was approx. $30 \mu \mathrm{m}$. The average total thickness of the layer, coupled with the outer and diffusive layers was approx. $50 \mu \mathrm{m}$. However, during the microstructure examination, areas of up to approx. $75-80 \mu \mathrm{m}$ thick were observed (Fig. 5).

This is probably due to uneven deposition of the
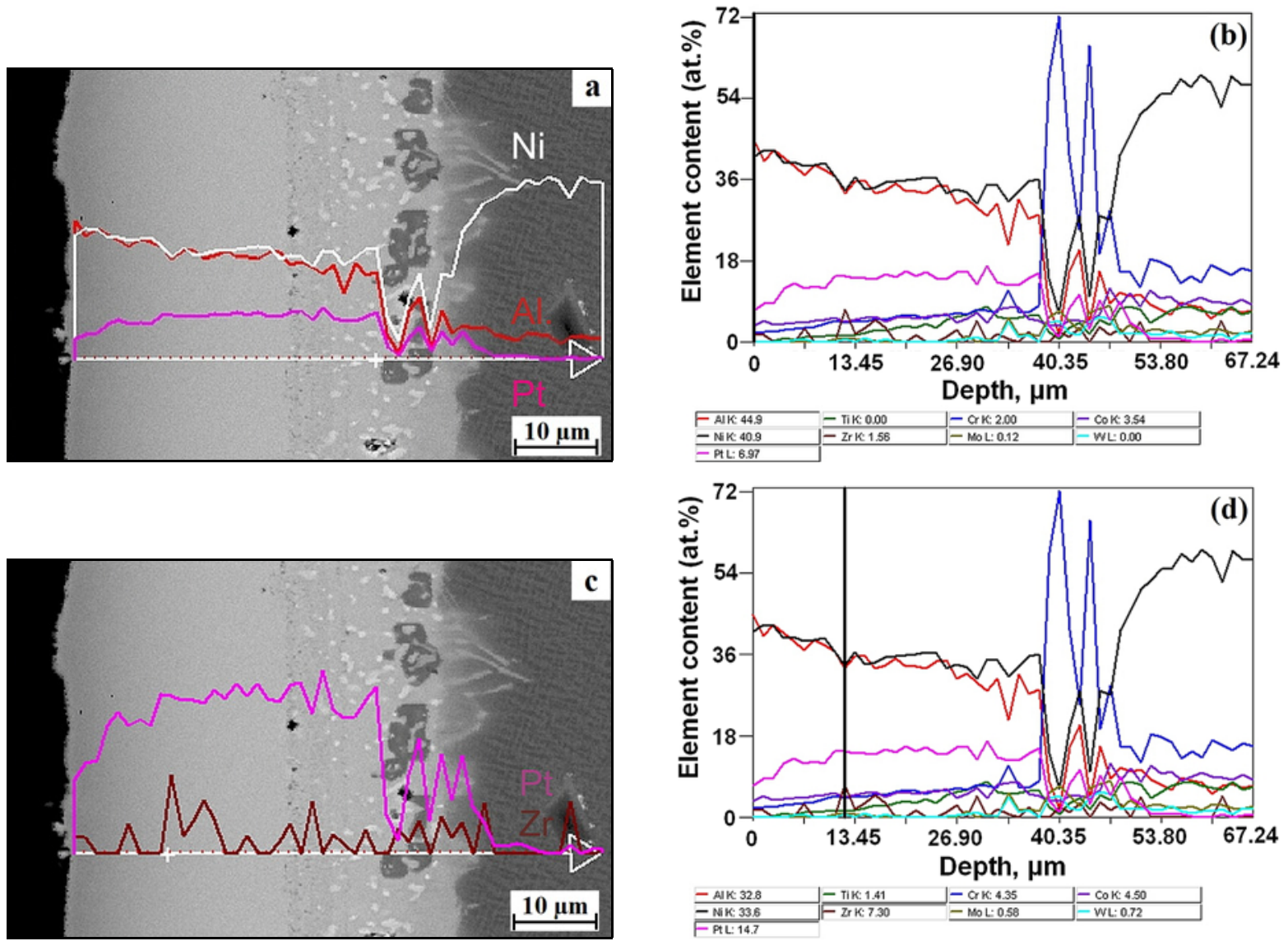

Fig. 7. Cross-section micrograph and EDS concentration profiles of some elements: aluminium, nickel, and platinum (a), distribution of some elements (b), distribution of platinum and zirconium (c), place of the highest concentration of zirconium, marked on the measuring line (d). 


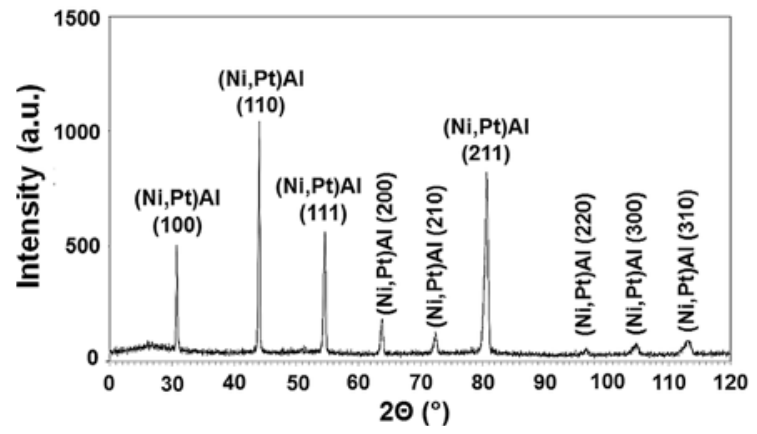

Fig. 8. XRD phase analysis results of zirconium modified $\beta$ - $(\mathrm{Ni}, \mathrm{Pt}) \mathrm{Al}$ aluminide coating.

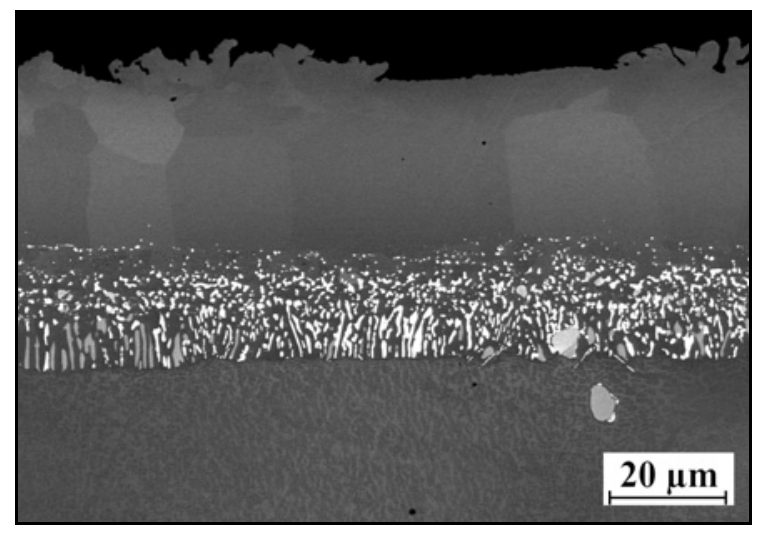

Fig. 9. The microstructure of $\mathrm{Pd}-\mathrm{Zr}$ modified aluminide coating deposited on Mar M200+Hf surface.

zone was variable and ranged from 45 at.\% to approx. 30 at. $\%$ within the depth-range of approx. $20 \mu \mathrm{m}$, from the surface towards the substrate material. Linear profile content of aluminium, nickel, and platinum content on the cross-section of the examined coating was variable. It was observed that on the surface of the aluminide coating platinum content was approx. 6 at. $\%$ and increased in a parabolic manner towards the substrate. Within the measurement range of $25-28 \mu \mathrm{m}$, the maximum platinum content was approx. 16 at.\%, and decreased to zero at a depth of approx. $60 \mu \mathrm{m}$.

On the coating surface, there was about 3.5 at.\% of Co, 2 at.\% of $\mathrm{Cr}$ and approx. 1.5 at.\% of $\mathrm{Zr}$. An increase in the content of refractory elements with a high melting point such as $\mathrm{Cr}, \mathrm{Co}, \mathrm{W}, \mathrm{Mo}$, and Ti was observed, in the direction from the surface aluminide coating towards the substrate. The maximum content of the refractory elements was observed in the interdiffusion zone - the maximum $\mathrm{Cr}$ and Co content was approx. 70 at.\%. Diffusion annealing of samples after the process could lead to levelling of the aluminium content layout of the cross-section of the examined coating and partial solution of particular elements as well as an insignificant increase in the coating thick-

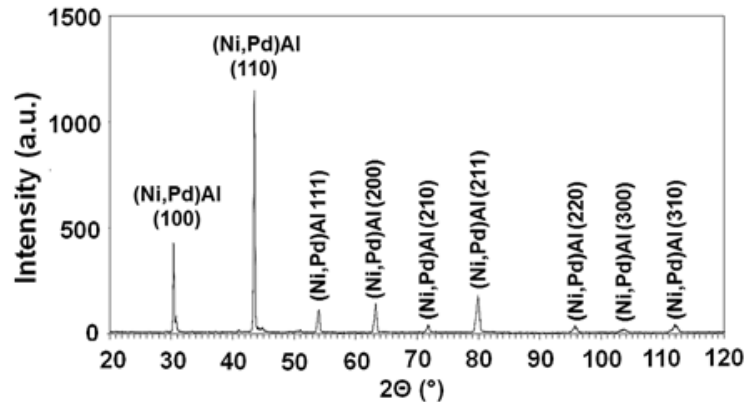

Fig. 10. XRD phase analysis results from the surface of Pd-Zr modified NiAl aluminide coating on Mar M 200+Hf substrate.
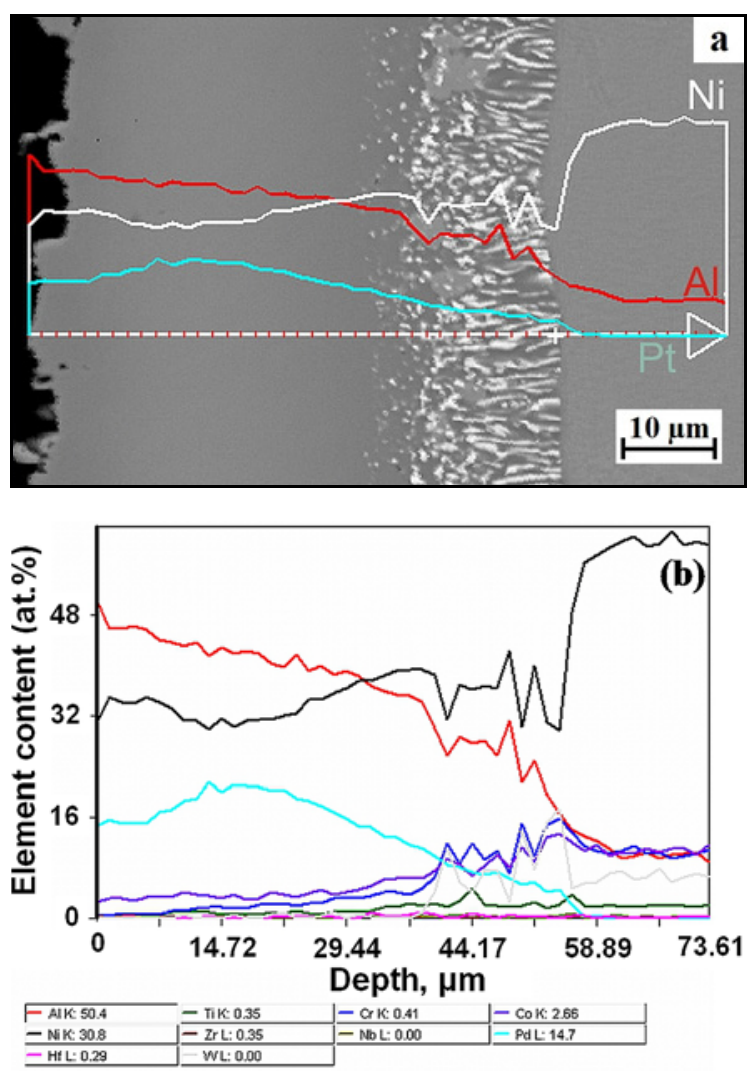

Fig. 11. Linear profile and distribution of some elements: nickel, aluminium, and platinum (a), a summary of selected elements (b).

ness. However, the samples were not heat treated after the CVD process.

Aluminium content in the platinum modified aluminide coating after the aluminizing/zirconizing process was approx. 45 at.\%, which corresponds to the aluminium content in the $\beta-\mathrm{NiAl}$ phase, in compliance with the Ni-Al binary phase diagram. The $\beta$-NiAl phase was confirmed in the XRD examination (Fig. 8). Based on the EDS linear microanalysis micro 


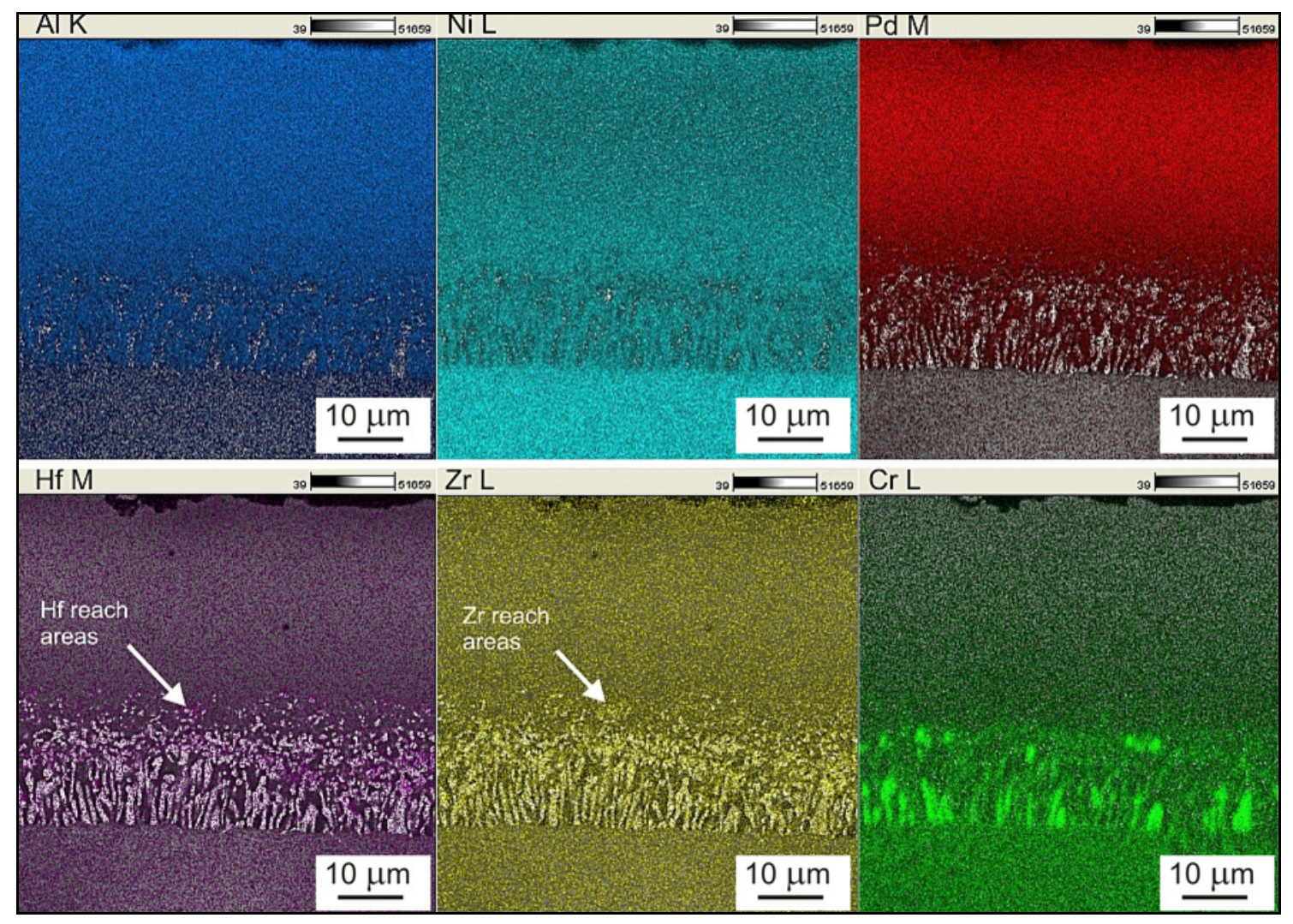

Fig. 12. EDS X-ray maps of Pd-Zr modified aluminide coating.

areas with increased zirconium content were observed (up to approx. 7 at.\%). In some micro areas of the outer layer, zirconium content was not noted. It may be assumed that zirconium with its high melting point formed ultrafine dispersed precipitates, which are difficult for SEM-EDS examination.

Studies of the microstructure were conducted on a cross-section of $\mathrm{Pd}-\mathrm{Zr}$ modified aluminide coatings (approx. $9 \mu \mathrm{m}$ ) obtained in the low-activity aluminizing-zirconizing CVD process on the substrate of Mar M200+Hf superalloy. Two zones were visible (Fig. 9). The observed outer layer consisted of grains of $\beta$-(Ni,Pd)Al phase, as confirmed by XRD analysis (Fig. 10). SEM-EDS microanalysis of the chemical composition showed that grains of $\beta-(\mathrm{Ni}, \mathrm{Pd}) \mathrm{Al}$ were enriched zirconium 0.35 at. $\%$ and hafnium 0.29 at.\%. Microanalysis of the SEM-EDS chemical composition (Figs. 11a,b) showed the typical linear distribution of nickel and aluminium content, typical for diffusive aluminide coatings.

Aluminium content on the coating surface and towards the interdiffusion zone was variable and decreasing, reaching a level of from approx. 50 at. $\%$ in the superficial area to approx. 34 at.\% on the boundary of the outer layer and the interdiffusion zone, at a depth of about $38 \mu \mathrm{m}$. Nickel content on the surface was approx. 30 at. $\%$, reaching the level of approx. 40 at. $\%$ in the diffusion zone and increasing up to approx. 60 at. $\%$ in the substrate material. Palladium content on the coating surface was approx. 16 at.\%, and within the range of depth $15 \mu \mathrm{m}$ towards the substrate, it reached the maximum level of approx. 21 at. $\%$, then decreasing linearly towards the substrate material and at a depth of approx. $58 \mu \mathrm{m}$ it equalled zero.

The total thickness of the outer zone, coupled with the interdiffusion zone was approx. $54 \mu \mathrm{m}$. The $\mathrm{Cr}$, Co, and $\mathrm{W}$ content on the surface of the coating is relatively low, that is lower than in the case of the coating that was not palladium modified. It has been observed that $\mathrm{Cr}$, Co, and $\mathrm{W}$ contents in the direction from the surface towards the diffusion zone were increasing, the highest amount is in the interdiffusion zone (max. 18 at.\% of each element). On the interface between an outer and interdiffusion zone, a range of fine (forming a chain) precipitates was observed (Figs. 12, 13a,b). One of the areas marked as containing such precipitates was EDS X-ray mapped (Fig. 14). Increased amounts of hafnium and zirconium were visible in these areas. Ultrafine precipitates were observed inside grains and similar larger precipitates on the GB's (Fig. 13a). Figure $13 \mathrm{~b}$ shows two precipitates, which were analyzed using EDS X-ray mapping technique. The results of this analysis are shown in Figs. 12, 14. This analysis showed that the particles visible in Fig. 13b contain an increased content of hafnium and zirconium. 

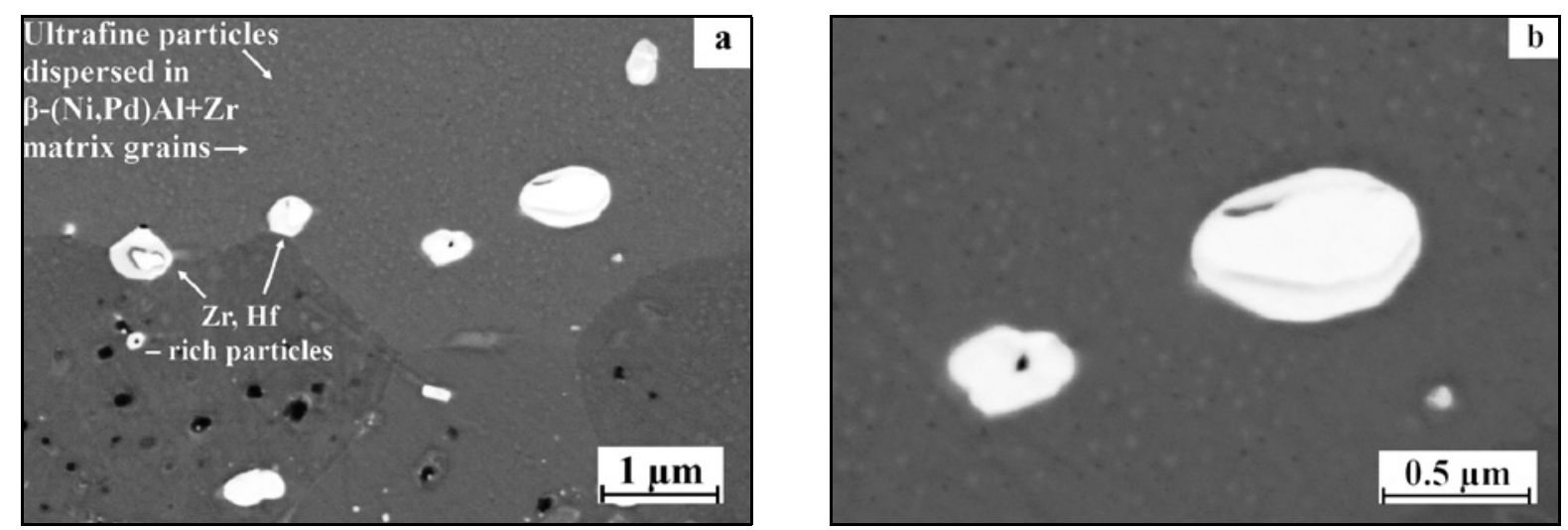

Fig. 13. Microstructure of (Ni,Pd)Al + Zr coating deposited on Mar M200+Hf substrate; in the phase boundary area morphology of ultrafine dispersed precipitates (a), larger $\mathrm{Hf}$ and $\mathrm{Zr}$-rich precipitates (b).
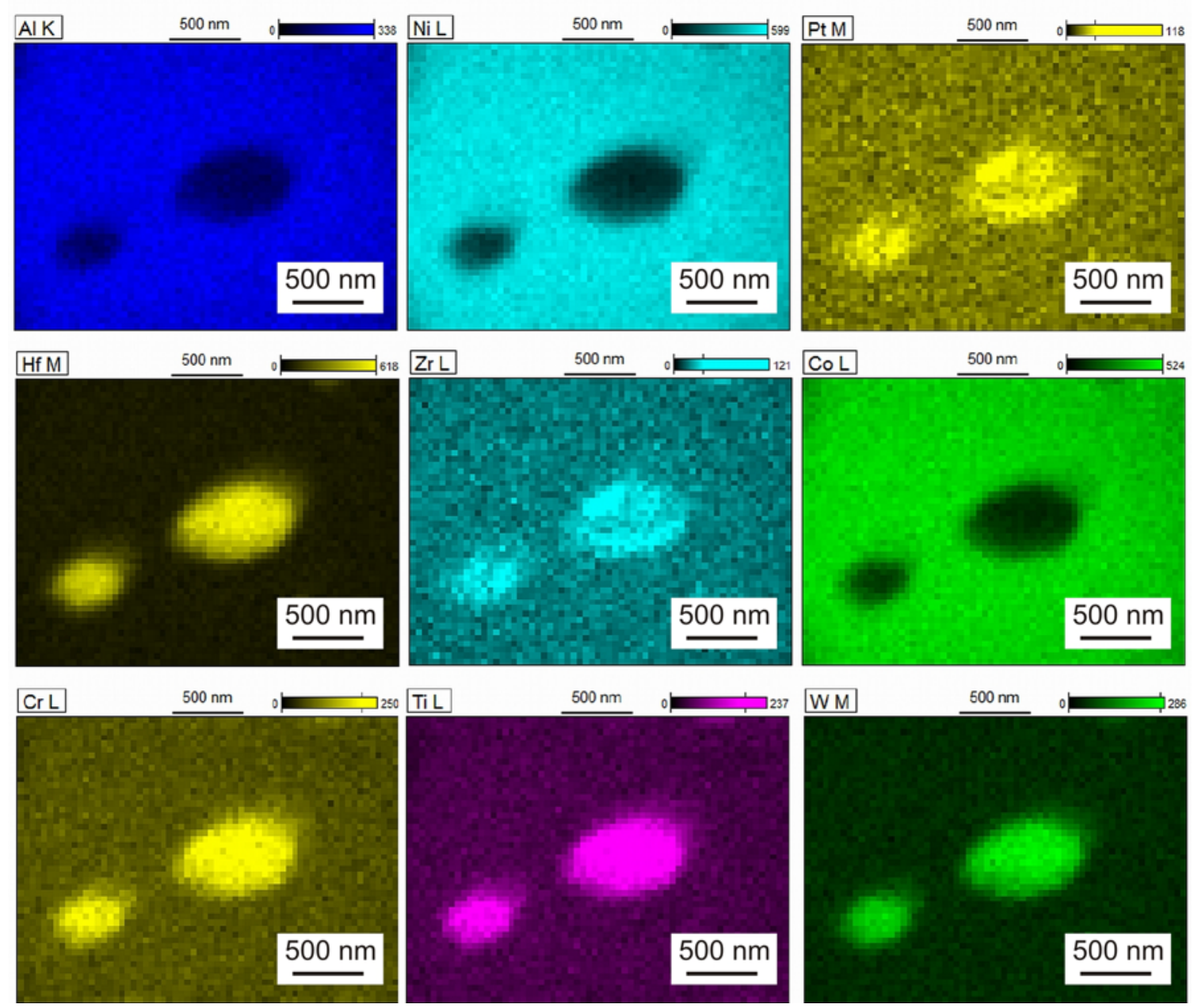

Fig. 14. Results of EDS X-ray mapping of precipitates on the boundary between an outer layer and interdiffusion zone.

\section{Summary}

On the substrate of René 80 superalloy, a compact and uniform platinum layer was obtained. However, on the substrate of Mar M200+Hf superalloy, a very smooth and uniform layer of palladium was obtained.
Both layers were clean, which was confirmed by EDS analysis of the chemical composition and XRD phase analysis. Aluminide coatings modified by the addition of platinum and palladium, and additionally modified with zirconium in the low-activity aluminizingzirconizing CVD process may be used alternatively 
instead of a NiCrAlY coating. Aluminide coatings produced in the low-activity CVD process are made of two distinct zones. The outer zone is made up of grains of the $\beta$-NiAl phase; the aluminium content is usually less than 50 at.\%. The outer layer also contains small amounts of other elements, especially chromium, titanium, and cobalt. In the interdiffusion zone, the aluminium content decreases, and the matrix is the $\gamma^{\prime}$-phase grains. In this zone, a significant increase in refractory elements $(\mathrm{Cr}, \mathrm{W}, \mathrm{Mo}, \mathrm{Co}, \mathrm{Ti})$ can be observed. The average thickness of both aluminide coatings was about 50 to $60 \mu \mathrm{m}$. Some areas of the layers were below $50 \mu \mathrm{m}$. The uneven electrodeposition of platinum and palladium layer may cause uneven growth of coating thickness, up to $80-90 \mu \mathrm{m}$. This causes differences in the coating thickness of about $20-30 \mu \mathrm{m}$. It was found that the aluminide coatings obtained contain more than 45 at.\% of Al. Further studies are required to determine the influence of lowactivity aluminizing-zirconizing CVD process parameters on the properties of aluminide coatings, e.g., heat resistance, thermal stability. Efforts are also made to try to determine the effect of CVD process parameters (time of zirconizing, time of aluminizing, flow rate of gaseous precursors) on the coating thickness and also aluminium content and its distribution. These coatings are used as a bond coat in thermal barrier coatings with an outer ceramic (top coat-YSZ) layer produced by EB-PVD or LPPS PS-PVD method.

\section{Acknowledgements}

Financial support of Structural Funds in the Operational Programme - Innovative Economy (IE OP) financed from the European Regional Development Fund Project "Modern Material Technologies in the Aerospace Industry," No. POIG.01.01.02-00-015/08-00 is gratefully acknowledged.

\section{References}

[1] Sieniawski, J.: Adv. in Man. Sc. and Tech., 27, 2003, p. 23.

[2] Koul, A. K., Immarigeon, J. P., Dainty, R. V., Patnaik, P. C.: In: Proceedings of the ASM 1993 Materials Congress: Advanced Materials and Coatings for Combustion Turbines. Eds.: Swaminathan, V. P., Cheruvu, N. S. Materials Park, ASM International 1993, p. 69.

[3] Sims, C. T., Stoloff, N. S., Hagel, W. C. (Eds.): Superalloys II. New York, John Wiley \& Sons Inc. 1987.

[4] Tamarin, Y.: Protective Coatings for Turbine Blades. Materials Park, ASM International 2002.

[5] Goward, G. W.: Surf. and Coat. Techn., 109, 1998, p. 73. doi:10.1016/S0257-8972(98)00667-7

[6] Stringer, J.: In: Proceedings of Materials Solutions '98. Ed.: Maziasz, P. J. Materials Park, ASM International 1999, p. 3.
[7] Bose, S.: High Temperature Coating. Oxford, Elsevier Science \& Technology Books 2007.

[8] Das, D. K., Singh, V., Joshi, S. V.: Metall Mater Trans A, 29, 1998, p. 2173. doi:10.1007/s11661-998-0042-0

[9] Xiang, Z. D., Burnell-Gray, J. S., Datta, P. K.: J Mater Sci, 36, 2001, p. 5673. doi:10.1023/A:1012534220165

[10] Clarke, D. R., Levi, C. G.: Ann Rev Mater Res, 33, 2003, p. 383. doi:10.1146/annurev.matsci.33.011403.113718

[11] Peters, M., Leyens, C., Schulz, U., Kaysser, W. A.: Adv Eng Mat, 3, 2001, p.193. doi:10.1002/1527-2648(200104)3:4<193::AIDADEM193>3.0.CO;2-U

[12] Goral, M., Kotowski, S., Sieniawski, J.: High Temp Mater Proc, 32, 2012, p. 33. doi:10.1515/htmp-2012-0051

[13] Yuan, F. H., Chen, Z. X., Huang, Z. W., Wang, Z. G., Zhu, S. J.: Corros Sci, 50, 2008, p. 1608. doi:10.1016/i.corsci.2008.02.002

[14] Niessen, K., Gindrat, M., Refke, A.: J Therm Spray Techn, 19, 2010, p. 502. doi:10.1007/s11666-009-9428-9

[15] Seserko, P., Hotz, J., Lemke, J., Smith, P. R., Mede, M.: EB PVD Thermal Barrier Coatings in Production. Hanau, ALD Vacuum Technologies AG 2002.

[16] Schütze, M.: Protective Oxide Scales and Their Breakdown. Chichester, John Wiley \& Sons 1997.

[17] Doychak, J., Ruhle, M.: Oxid Met, 31, 1989, p. 431. doi: $10.1007 / \mathrm{BF} 00666466$

[18] Sauthoff, G.: Intermetallics. Weinheim, VCH Verlagsgesellschaft 1995.

[19] Briks, N., Meier, G. H., Pettit, F. S.: Introduction to the High-Temperature Oxidation of Metals. Cambridge, Cambridge University Press 2006.

[20] Bouchaud, B., Balmain, J., Pedraza, F.: Oxid Met, 69, 2008, p. 193. doi:10.1007/s11085-008-9092-3

[21] Warnes, B. M., Punola, D. C.: Surf Coat Tech, 94-95, 1997, p. 1. doi:10.1016/S0257-8972(97)00467-2

[22] Pytel, M., Góral, M., Maliniak, M.: Arch Mater Sci Eng, 53, 2012, p. 102.

[23] Swadźba, R., Hetmańczyk, M., Wiedermann, J., Swadzba, L., Moskal, G., Witala, B., Radwański, K.: Surf Coat Tech, 215, 2013, p. 16. doi:10.1016/j.surfcoat.2012.06.093

[24] Swadzba, R., Hetmańczyk, M., Sozańska, M., Witala, B., Swadzba, L.: Surf Coat Tech, 206, 2011, p. 1538. doi:10.1016/j.surfcoat.2011.06.042

[25] Swadzba, L., Nawrat, G., Mendala, B., Goral, M.: Key Eng Mater, 465, 2011, p. 247. doi:10.4028/www.scientific.net/KEM.465.247

[26] Fisher, G., Datta, P. K., Burnell-Gray, J. S.: Surf Coat Tech, 113, 1999, p. 259. doi:10.1016/S0257-8972(99)00008-0

[27] Bouchaud, B. Balmain, J., Pedraza, F.: Oxid Met, 69, 2008, p. 193. doi:10.1007/s11085-008-9092-3

[28] Henderkott, J. P.: Mechanisms Associated with Rumpling of Pt-Modified $\beta$-NiAl Coatings. [MSc. Thesis]. Ames, Iowa State University 2007.

[29] Tolpygo, V. K., Clarke, D. R.: Acta Mater, 52, 2004, p. 615 . doi:10.1016/j.actamat.2003.10.001

[30] Tolpygo, V. K., Murphy, K. S., Clarke, D. R.: Acta Mater, 56, 2008, p. 489. doi:10.1016/j.actamat.2007.10.006 
[31] Bacos, M. P., Dorvaux, J. M., Landais, S., Lavigne, O., Mevrel, R., Poulain, M., Rio, C., Vidal-Setif, M. H.: Aerospace Lab Journal, AL 03-04, 2011, p. 1.

[32] Marino, K. A., Hinnemann, B., Carter, E. A.: In: Proceedings of the National Academy of Sciences of the United States of America 2011. Washington, PNAS 2011, p. 5480. doi:10.1073/pnas. 1102426108
[33] Zagula-Yavorska, M., Sieniawski, J., Gancarczyk, T.: Arch Metall Mater, 57, 2012, p. 504. doi:10.2478/v10172-012-0052-1 